\title{
The thoughts of the 2nd graduate students of the Faculty of Medicine about anatomy practice exams
}

\section{Tıp Fakülltesí 2.sınıf öğrencilerinin anatomi uygulama sınavları hakkındaki düşünceleri}

Yaşar Taştemur, Vedat Salbancıŏulları*

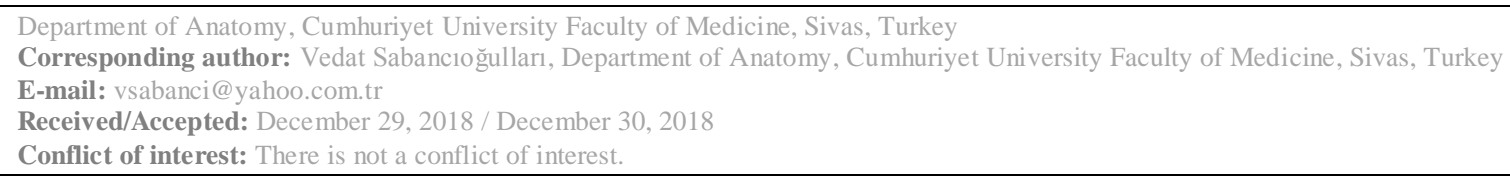

\section{SUMMARY}

In assessing the adequacy and effectiveness of medical education, concrete data, and evidence-based information are essential. Especially taking the opinions and suggestions of the students is guiding the direction of medical education. Therefore, in our study, a questionnaire consisting of twelve questions was applied. The aim of this the present study is to determine the thoughts and suggestions of the second year medical faculty students about anatomy practice courses. The study included 139 volunteers 2nd-grade medical faculty student (104 female and 35 male students) who agreed to answer the questionnaire. While $55.4 \%$ of the students thought that the time allocated for anatomy applications was sufficient, $61.15 \%$ stated that they would participate in the practical courses even though the lecture attendance would not be taken during the course. Almost all of the students $(98.6 \%)$ want their instructors to make models or cadaveric demonstrations during the laboratory practices. $82.73 \%$ of the students think that the anatomy practice exams are required at the end of the committee and $75,53 \%$ of them think that the measurement and evaluation of the examination by using cadaver, model, and bone on the tables is more appropriate. Besides, $91.36 \%$ of the students stated that the study notes should be given before the practice of anatomy.

The feedback from the students shows that the practical lessons in understanding human anatomy are of vital importance and the majority of students accepts the current practices. However, evaluation of the requested applications would facilitate understanding of subjects and increases success. In the preparation of training programs, the inclusion of clinical anatomy into the curriculum may be useful in improving the quality of medical education.

Keywords: anatomy, questionnaire, medical education.

\section{ÖZET}

Tıp eğitiminin yeterliliğinin ve etkinliğinin değerlendirilmesinde somut veriler ve kanıta dayalı bilgiler önemlidir. Özellikle öğrencilerin görüş ve önerilerinin alınması tıp eğitiminin yönlendirilmesinde yol gösterici olmaktadır. Bu sebeple, çalışmamızda on iki sorudan oluşan anket formu uygulanarak, C.Ü. tıp fakültesi ikinci sınıf öğrencilerinin anatomi uygulama dersleri hakkındaki düşünceleri ve önerilerinin belirlenmesi amaçlanmıştır.

Çalışmaya anket sorularını cevaplamayı kabul eden 104'ü kadın, 35’i erkek 139 gönüllü öğrenci dahil edildi. Öğrencilerin \%55,4'si anatomi uygulamalan için ayrılan sürenin yeterli olduğunu düşünürken, \%61,15'i ders esnasında yoklama alınmasa da, uygulama derslerine katılacağını belirtmiştir. Öğrencilerin hemen hemen tamamı $(\% 98,6)$ laboratuvar uygulamaları esnasında öğretim elemanlanı tarafindan maket ya da kadavra anlatımı yapılmasını istemektedir. Öğrencilerin \% 82,73 ü komite bitiminde yapılan anatomi pratik sinavlarını gerekli bulmakta ve \%75,53’ü masalar üzerine kadavra, maket ve kemik konularak yapılan zilli sunavın ölçme ve değerlendirme de daha uygun olduğunu düşünmektedir. Ayrıca öğrencilerin \%091,36'sı anatomi pratiğinden önce, çalışma notlarının verilmesi gerektiğini ifade etmişlerdir.

Öğrencilerden alınan geribildirimler göstermektedir ki, insan anatomisinin anlaşılmasında uygulama dersleri hayati öneme sahip olup, mevcut uygulamalar öğrencilerin büyük çoğunluğu tarafindan kabul görmektedir. Bununla birlikte talep edilen uygulamalarda eğitimciler tarafından değerlendirilip, staj konularının anlaşılmasını kolaylaştırmakta ve 


\section{INTRODUCTION}

The aim of medical education in the declaration of Edinburgh has been mentioned as to create medical doctors who will improve the health of humankind overall ${ }^{1}$. It is the responsibility of the trainer to create a good educational environment ${ }^{2}$. In order to achieve this goal nowadays, studentcentered approaches are needed rather than traditional lectures and instructor-centered approaches ${ }^{3}$. The basis of the student-centered approach in education is feedback.

The anatomy course has taken a prominent place in the basic sciences education programs of medical faculties throughout history ${ }^{4}$. Most of the Anatomy education is taken at $1 \mathrm{~s}$ and 2 nd grades in our faculty.

It is well known that if the education approach covers most of the senses, it is easier to learn and difficult to forget ${ }^{5}$. In the anatomy course, the application courses are essential in this respect. In our anatomy practice courses, audiovisual and tactile education are given together.

For these reasons, in order to determine the thoughts of our students in anatomy practice courses, we applied a questionnaire form consisting of 12 questions and received feedback.

\section{MATERIAL AND METHODS}

One hundred thirty-nine medical faculty students who took theoretical and practical anatomy courses and accepted to answer the questionnaires were included in the study. A questionnaire consisting of twelve questions was used in the study. The students were asked not to write a name for the questionnaire in order to express their ideas more clearly and objectively. In this way, it was aimed to increase the reliability of the research. The answers to the questions were uploaded to SPSS 15.0 program for statistical evaluation.

The following questions were included in the questionnaire.

1. Is the practice hours sufficient for the practice of Anatomy?

2. Would you like to attend lecture practice courses, even if the attendance would not be taken?
3. Do you make preparations before Anatomy practice course?

4. Should an exam be given from anatomy practice courses at the end of each committee?

5. Which of the following methods should be preferred in the practice exams?

A) Classic smart test done by placing models and cadavers on tables

B) Oral examination by asking for the formations on the model and cadaver

C) A digital test performed by projecting images of the model and cadaver from the projector.

6. Is the time given to answer each question during the practice of an anatomy practice sufficient?

7. Is the number of questions in the practice exam sufficient?

8. Should the questions which contain illustrations or pictures be asked in the theoretical examinations?

9. Should the photographs of models in the laboratory be used along with images of the anatomy atlas in classic theoretical lessons?

10. Should instructors explain models or cadavers during laboratory applications?

11. Are the sources (lecture note, powerpoint, anatomy atlases, anatomy books, animations, etc.) sufficient for the preparation of the practical courses?

12. Should the study notes be given before the application courses?

\section{RESULTS}

Of the students included in the study, 104 were female and 35 were male, and the mean age was 21.34 (19-28 years). While $77(55.4 \%)$ of the students thought that the time allocated for anatomy applications was sufficient, 50 (36\%) students stated that this period should be increased.

$85 \%(61.15 \%)$ of the students stated that they would participate in the practical courses even if 
the attendance would not be taken, while 28 (20.14\%) stated that they would not participate. 25 students were undecided about this situation.

$57(41 \%)$ of the students stated that they did not make any preparations before they came to the anatomy practice courses, while 55 (39.56\%) stated that they worked on the laboratory subject beforehand.

While $115(82.73 \%)$ of the students thought that the anatomy practice exams were necessary at the end of the committee, 18 (12.94\%) stated that there was no need to practice the anatomy at the end of the committee.

$105(75.53 \%)$ of the students thought that the measurement and evaluation of the cymbal exam with cadaver, model, and bone were more appropriate, while $24(17,26 \%)$ of them were verbal and $10(7,19 \%)$ stated that digital examination can be done.

While $70(50.35 \%)$ of the students stated that the duration of the answer should be increased for each question, 60 (43.16\%) students declared that the duration was sufficient.

$70(50.35 \%)$ students stated that the number of questions in the practical exams was sufficient, and $50(35.97 \%)$ of the students said that the number of questions should be increased.

While $67 \quad(48.20 \%)$ students did not want questions with pictures and illustrations in theoretical examinations, $61(43.88 \%)$ students think that they should have questions with pictures and illustrations in the theoretical examination.

$108(77.69 \%)$ of the students wanted to use the photographs of models in the laboratory as well as the images of anatomy atlas and according to 20 $(14.38 \%)$ students, this was not necessary.

Almost all of the students want their instructors to explain the lesson topic during anatomy practice and make a demonstration on the models and the cadaver $137(98.6 \%)$.

$58(41.72 \%)$ of the students thought that the lecture resources given during the theoretical lecture were sufficient to prepare for the practice of anatomy, while $50(35.97 \%)$ found these resources insufficient. 29 (20.86\%) students were undecided about the adequacy of the course resources.

$127(91.36 \%)$ of the students suggested that the study notes should be given before the anatomy practice.

\section{DISCUSSION}

The feedback we obtained in our study has been guiding about anatomy practice courses. The time allocated to the application course was found sufficient by $55.4 \%$ of our students. It is a positive finding that more than half of our students think that it is sufficient, but we think that it is appropriate to increase the practice hours in order to ensure that the rate of adequacy is higher.

In a study by Turan et al; $56.3 \%$ of the students found that the practice hours were sufficient, while $43.7 \%$ of the students stated that they should be increased ${ }^{6}$. Although the same course hours are not applied, it has a very similar course time with our curriculum.

One of the issues that should be considered in our study is the low level of preparedness of the students in the application courses. $41 \%$ of our students stated that they did not make any preparations before coming to anatomy practice classes. In another study conducted on this subject, researchers found that $63.1 \%$ of the students participated in the anatomy practice courses without any preliminary preparation and $29.1 \%$ did not even know the subject of the course 6

Anatomy practice exams are done in one day before the theoretical examination at the end of the committee. While $82.7 \%$ of the students thought that these exams were required, $12.9 \%$ of the students stated that there is no need to practice anatomy at the end of the committee. Similarly to our study, Tuygar et al. (70.6\%) found that the practical exam is necessary for the evaluation of anatomy education ${ }^{7}$. Despite the difficulty and stress of the exam, The students still believe the need for an exam to test their knowledge about anatomy practices. This is a good indicator to show that their awareness of the profession is at a good level.

As it is known, how the examination is done is as important as the exam questions. In our faculty, $75,5 \%$ of our students believe that the exams which are made by placing cadavers, models, and bones on the tables and done with a cymbal are appropriate. The other two methods in our survey, verbal and digital exams, are supported by our student with the percentages $17.2 \%$ and $7.1 \%$, respectively. These results showed us that our method is accepted by the students. Similarly, Ögetürk et al. Conducted an examination which also uses a cymbal, at Frrat University Medical School, $92 \%$ of the students stated that the exams were effective and according to $8 \%$ of students, 
exams were ineffective ${ }^{8}$. However, in the study conducted in Uludag University Faculty of Medicine in where a verbal examination was applied, $68 \%$ of the students stated that they found it helpful to have an oral examination at the end of the study ${ }^{6}$. The reason for cymbal-exam method is prefered over oral exam might be that all students are asked the same questions, equal time is given to everyone and less excitement. The digital exam is the less preferred one. We believe that the reason for that might be that it is an unknown and unexperienced method. When the results of these two studies are evaluated, it is thought that the students tend to prefer the examination method which they already used to.

In our anatomy practice exams, we give 30 seconds for each question. In our study, $50.3 \%$ of the students stated that during the exam the response time for each question should be increased and $43.1 \%$ stated that the duration was sufficient. In addition, in a study conducted in four universities, $28.1 \%$ of the students stated that the duration of the practical exams was sufficient ${ }^{6}$. These responses of our students suggest that we should consider increasing duration per question.

Visual learning method of anatomy is not only practical but must be reflected in theoretical courses and exams. For this purpose, we asked the question whether you want to have questions which has pictures and illustrations in theoretical exams and $48.2 \%$ of students gave a negative answer, while $43.8 \%$ of the students said that they should have visual questions in the theoretical examination. In the study of Tuygar et al., The ratio of students who wanted to have pictorialshaped questions in theoretical tests was found to be $44.4 \%$ similar to our study ${ }^{6}$. In addition, $90 \%$ of the students in the study of Ögetürk and his friend's, pictorial questions in the theoretical exam found positive, $10 \%$ of the students reported negative opinion. We thought that it would be useful to reduce the separate thinking of anatomy practice and theory and to make students understand that anatomy is a theoretical and practical visual whole.

We use anatomy atlas images in the lecture. When we asked the opinions of the students about the use of models in theoretical courses in terms of preparation for the laboratory and familiarity with the models, $77.6 \%$ of the students stated a positive opinion and 14.3 students stated that it was not necessary. In the study of Acuner et al., The rate of students who think that audio-visual tools are not used sufficiently in the learning process is found to be $54.8 \%{ }^{8}$.
In medical faculties, anatomy practice courses are taught with different methods. In our practice, models and cadavers are explained by instructors. In our study, almost all of our students stated that they found the model or cadaveric explanation by instructors during the laboratory applications by the instructors during the laboratory applications positive. Similarly to our study, $87.4 \%$ of the students in the study of Ögetürk et al. declared that they found effective listening to the table's responsible instructor in laboratory studies ${ }^{7}$.

In our study, $41.7 \%$ of the students think that the resources given during the lectures are sufficient to prepare for the practice of anatomy and $35.97 \%$ of them think that these resources are insufficient. The question "In order to provide better preparation for laboratory work, which should be given more time in the theoretical courses?" of Ögetürk et al. is answered by $76 \%$ of the students as atlas paintings, $57.5 \%$ of the students as cadaver paintings .

One of the important results we achieved in this study was that the rate of students who wanted to give pre-laboratory study notes was $91.3 \%$. We believe that mostly the students who were short on their preparations before the anatomy practice answered this question positively and they will benefit the most if the notes are shared before the practice.

In order to ensure the development of education in the medical school, students should be given feedback periodically and shared with the students and trainers. It is a useful method to use these feedback and evaluations in program changes.

\section{REFERENCES}

1. Edinburgh Decleration of WFME. World Conference on Medical EducationReport, 7-12 August 1988, Edinburgh, Blackwood Pillans \& Wilson, Edinburgh.

2. Çizmeci O, Dinççağ A, Değerli Ü. Olumlu bir öğrenim ortamı yaratmak. Tip Ĕgitimi Dünyasl, 2001; 4.

3. Elizondo-Montemayor LL. How we assess students using an holistic standardized assesment system? Medical Teacher, 2004; 26: 400-402.

4. Carmichael SW, Pawlina W. Animated powerpoint as a tool to teach anatomy. Anatomical Record, 2000; 261: 83-88.

5. Seferoglu SS. Öğretim Teknolojileri ve Materyal Tasarımı. ISBN: 9944-919-10-1

6. Turan ÖS, Cankur NŞ, Kurt MA. Tıp Fakültesi Öğrencilerinin Anatomi Uygulamaları Hakkındaki Görüşleri: Bir 
Geri Bildirim Örneği. Uludağ Üniversitesi Tıp Fakültesi Dergis, 2001; 27: 1-8.

7. Öğetürk M, Kavaklı A, Kuş İ, Songur A, Zararsız İ, Sarsılmas M. Tıp öğrencileri nas1l bir anatomi eğitimi istiyor? Tlp Ĕ̈itimi Dünyasl, 2003; 10: 7-13.

8. Acuner AM, Yalçın M, Ersoy M, Tekdemir İ, Ersoy F. Ankara Üniversitesi Tıp Fakültesi anatomi dersine ilişkin öğretme-öğrenme sürecinin değerlendirilmesi. Ankara Üniversitesi Tip Fakültesi Mecmuası, 1999; 52:211218. 